\title{
THE IMPACT OF CAPITAL GAINS TAXES ON STOCK PRICE REACTIONS TO S\&P 500 INCLUSION
}

\author{
Jennifer Blouin \\ Jana Smith Raedy \\ Douglas A. Shackelford \\ Working Paper 8011 \\ http://www.nber.org/papers/w8011 \\ NATIONAL BUREAU OF ECONOMIC RESEARCH \\ 1050 Massachusetts Avenue \\ Cambridge, MA 02138 \\ November 2000
}

We appreciate helpful comments from participants at financial economics, public finance and accounting workshops at Duke and the University of North Carolina on a predecessor paper (Capital Gains Taxes and Stock Reactions to Quarterly Earnings Announcements) in which this research was originally discussed. The views expressed in this paper are those of the authors and not necessarily those of the National Bureau of Economic Research.

(C) 2000 by Jennifer L. Blouin, Jana Smith Raedy, and Douglas A. Shackelford. All rights reserved. Short sections of text, not to exceed two paragraphs, may be quoted without explicit permission provided that full credit, including (C) notice, is given to the source. 
The Impact of Capital Gains Taxes on Stock Price Reactions to S\&P 500 Inclusion Jennifer L. Blouin, Jana Smith Raedy, and Douglas A. Shackelford NBER Working Paper No. 8011

November 2000

JEL No. H24, G12, G14, H22

\begin{abstract}
This paper contributes to our understanding of the determinants of price responses to inclusion in the S\&P 500 by providing evidence consistent with capital gains tax planning impacting stock reactions. Tests are conducted on 426 additions from 1978-1999. We regress the returns on the first trading day following announcement on a capital gains tax measure and controls. The evidence is consistent with the share prices of appreciated firms being temporarily bid up to compensate individual shareholders for any unanticipated capital gains taxes triggered when they sell to index funds and the share prices of depreciated firms being temporarily diminished when individual shareholders sell because buyers and sellers share the tax savings associated with deductible capital losses. We infer from these findings that in rebalancing their portfolios after S\&P 500 additions, index funds share individual shareholders' capital gains taxes (or tax savings) through sales price adjustments. Consistent with temporary price pressure, further analysis shows that much of the price reaction unwinds over the following week's trading. Finding that personal capital gains taxes affect stock returns in a setting that does not bias toward taxes mattering suggests that capital gains tax capitalization may be a pervasive feature in equity valuation.
\end{abstract}

Jennifer L. Blouin

Kenan-Flagler Business School

University of North Carolina

Campus Box 3490, McColl Building

Chapel Hill, NC 27599-3490

Douglas A. Shackelford

Kenan-Flagler Business School

University of North Carolina

Campus Box 3490, McColl Building

Chapel Hill, NC 27599-3490

and NBER

doug_shack@unc.edu
Jana Smith Raedy

Kenan-Flagler Business School

University of North Carolina

Campus Box 3490, McColl Building

Chapel Hill, NC 27599-3490 


\section{The Impact of Capital Gains Taxes on Stock Price Reactions to S\&P 500 Inclusion}

Positive abnormal returns of 3-4 percent are typical on the first trading day after the Standard \& Poor's Corporation announces an addition to its 500 Stock Index (see Shleifer (1986) and Harris and Gurel (1986), among others). One explanation for these price increases is upward price pressure created by a surge in demand from passive funds and other portfolio managers who track the 500 index. ${ }^{1}$ For example, Harris and Gurel (1986) and Lynch and Mendenhall (1997) document that both share prices and trading volume soar when firms join the S\&P 500 . They infer that prices rise to attract enough shares to meet the demand of index funds who are rebalancing their portfolios to mitigate tracking error between their returns and the index's return. When the rebalancing is completed, prices return to prior levels.

This paper extends the price pressure hypothesis to include taxes. If funds are acquiring shares of new additions from taxable shareholders, then the acquisitions generate taxable capital gains or losses to selling shareholders. This paper investigates whether these capital gains or losses affect the pricing of securities entering the S\&P 500.

We predict that the tax ramifications of a sale affect a stock's price in the following manner. The share prices of appreciated firms are temporarily bid up to compensate individual shareholders for any unanticipated capital gains taxes triggered when they sell to index funds. The share prices of depreciated firms are temporarily diminished when individual shareholders sell because buyers and sellers share the tax savings associated with deductible capital losses.

The logic is as follows. Taxes (or tax savings) vary with the amount of a stock's appreciation and across types of taxpayers (i.e., individuals, corporations, tax-exempts, etc.).

\footnotetext{
${ }^{1}$ Other explanations include long-run downward sloping demand curves (e.g., Shleifer (1986)) and information effects arising from the implied certification of a firm's financial strength associated with inclusion, (e.g., Jain (1987), Dhillon and Johnson (1991)). See further discussion in Kaul, Mehrotra, and Morck (2000).
} 
This variation should affect the sources from which index funds purchase their shares and the price at which they trade. For example, from a tax perspective only, we would expect that index funds first acquire shares from taxable shareholders with depreciated shares (i.e., tax basis exceeds market price). Because realized losses are deductible, these shareholders have a tax incentive to sell and thus should be willing to accept lower bids than other potential selling shareholders. $^{2}$

Investors in the highest tax brackets enjoy the greatest tax savings from selling depreciated equity. Among individuals, the tax savings further vary with the length of time that the stock has been owned. Generally, losses on investments held for one year or less (short-term capital losses) are deducted against gains of similar duration (short-term capital gains), providing up to 39.6 cents of savings per dollar of loss under current law. ${ }^{3}$ Conversely, losses on investments held longer (long-term capital losses) are initially deducted against tax-favored longterm capital gains, refunding only 20 cents per dollar of loss. Thus, individual investors have incentives to sell depreciated shares before long-term qualification because short-term capital losses recover 19.6 cents more per dollar of loss in tax savings than long-term capital losses. When the supply of depreciated shares is exhausted, the next least costly source of equity (from a tax perspective) is shares held by shareholders who face no tax consequences on their sale of stock (e.g., tax-exempt organizations, tax-deferred pension plans, foreign investors, and taxable shareholders whose tax basis equals market price). ${ }^{4}$ When the supply of tax-exempt

\footnotetext{
${ }^{2}$ Both individuals and corporations face limitations on the immediate deductibility of capital losses. Currently individuals are limited to an annual $\$ 3000$ deduction for capital losses in excess of capital gains. Corporations cannot deduct capital losses in excess of capital gains.

${ }^{3}$ Complex rules govern the netting of capital gains and losses. The first netting offsets gains and losses of similar duration. Footnote 12, however, briefly describes conditions that render distinctions between short-term and longterm irrelevant. See Shackelford (2000) for a more detailed discussion.

${ }^{4}$ Among our sample of S\&P 500 additions, we find that 48 percent of the shares are held by institutions filing form 13-F. Three percent are in pensions and other organizational forms that clearly avoid personal taxation. The remaining shares are held by mutual funds ( 29 percent), banks ( 11 percent), and insurance companies ( 5 percent).
} 
shares are exhausted, the next least costly source is individual shareholders who have held their shares long enough to qualify for the above-mentioned tax-favored long-term capital gains tax rate, which caps at 20 percent. After exhausting these individual investors, the next supply is corporate investors who face a 35 percent capital gains tax rate..$^{5}$ The final supply of shares for index funds is the least tax-efficient source, individual investors facing tax-disfavored short-term capital gain tax rates (the current maximum federal rate is 39.6 percent). Because the short-term capital gain tax rate is up to 19.6 cents more than the long-term capital gains tax rate, individuals have incentives to defer selling appreciated shares until they quality for long-term capital gains treatment or demand compensation for selling early and incurring incremental short-term capital gains taxes in excess of long-term capital gains taxes.

We conjecture that the incentives to realize short-term capital losses (as opposed to longterm capital losses) and long-term capital gains (as opposed to short-term capital gains) affect the price that index funds must pay to attract sufficient equity to meet their needs for index additions. If individuals hold shares whose sale would trigger favorably deducted short-term capital losses, the reservation price should be lower than if those shares face long-term capital loss treatment. Similarly, if individuals hold shares whose sale would generate favorably taxed long-term capital gains, they will demand less compensation (through higher sales prices) than if their sale would create tax-disfavored short-term capital gains.

\footnotetext{
Determining the extent to which these shares are subject to individual taxation is problematic. The capital gains and losses on individuals' tax returns are affected by many investments, including personal holdings, street-name holdings, trusts, mutual funds, partnerships, S corporations, limited liability corporations, and other entities that pass-through taxable gains and losses. Thus, the taxation of many shares held by financial institutions may flow directly to individual tax returns. However, individuals also hold shares through many accounts that are unaffected by the personal taxation, such as closely-held $\mathrm{C}$ corporations, individual retirement accounts, 401(k) retirement accounts, and other defined contribution plans. Mutual funds are particularly problematic because individual holdings can be either taxable or non-taxable.

${ }^{5}$ Before 1987, corporations also enjoyed favorable long-term capital gains tax rates. For example, from 1979-1986, the maximum statutory corporate long-term capital gains tax rate was 28 percent while other corporate taxable income was taxed at a maximum statutory tax rate of 46 percent.
} 
Although these incentives should apply to all security sales, we focus on sales triggered by events (1978-1999 S\&P 500 inclusions) that are known to cause unusually large stock reactions and thus amplify any possible tax distortion. Our tests are designed to assess whether share price responses to S\&P 500 additions are consistent with (a) individual shareholders of depreciated stock selling at a discount to ensure favorable short-term capital losses and avoid long-term capital losses and (b) individual shareholders of appreciated stock (who had anticipated selling at favorable long-term capital gains tax rates) selling at a premium to forgo long-term capital gain treatment and be taxed at the higher short-term capital gains tax rate.

Consistent with these incentives affecting sales prices, we find that on the first trading day following announcement, stock returns are increasing in our measure of the incremental tax difference between short-term and long-term treatment. ${ }^{6}$ We infer that individual investors share their incremental tax savings (taxes) from selling depreciated (appreciated) stock with acquiring index funds through stock price adjustments. Approximately half of the price response reverses during the week following the announcement, implying that the much of the effect is temporary. The price impact is not trivial. For the mean firm, we estimate that capital gains taxes account for one-day abnormal returns of 0.48 percent (121 percent annualized) and a standard deviation increase in taxes boosts one-day abnormal returns by 1.02 percent ( 257 percent annualized).

The analysis includes two recent high-profile additions of appreciated firms that illustrate the possible price impact associated with compensating individual investors to sell before qualifying for the favorable long-term capital gains taxes. ${ }^{7}$ On December 22, 1998, S\&P announced that America Online would be added to its 500 index following trading on December

\footnotetext{
${ }^{6}$ Incremental taxes are computed as the product of a tax base (recent share appreciation) and a tax rate (the spread between short-term and long-term capital gains tax rates).

${ }^{7}$ Inferences are qualitatively unaltered if these two additions are excluded from the analysis.
} 
31, 1998. During the intervening seven trading days, its stock jumped 33 percent, compared with a 2 percent increase in the S\&P 500. Similarly, on November 30, 1999, Standard \& Poor's announced that Yahoo! would be added to its 500 index one week later. During that week Yahoo!'s share price soared 64 percent while the S\&P 500 rose only 1 percent.

These extraordinary price surges are difficult to explain (Shleifer (2000, pp. 22-23)), and we do not claim that taxes are a primary factor. However, compensation for individual investors' short-term capital gains taxes could partially explain these responses to S\&P 500 inclusion. Individuals likely held a disproportionate number of both America Online and Yahoo!'s shares, had purchased many during the preceding year as America Online rocketed 452 percent and Yahoo! jumped 122 percent, and intended to retain the shares until they qualified for favorable long-term capital gains tax treatment. ${ }^{8}$ If the supply of shares held by investors, other than individuals in short-term positions, was insufficient to meet the demand by index funds, then index funds may have been forced to bid up the price of shares to entice individual shareholders to sell before long-term capital gains qualification. ${ }^{9}$

This paper makes two contributions that should interest scholars and policymakers. First, it sheds additional light on the puzzling returns associated with index additions. To our knowledge, this is the first paper to assert and document that taxes affect price responses. Since most additions are firms that have experienced recent appreciation, these tax incentives usually boost stock returns at the announcement date.

\footnotetext{
${ }^{8}$ Unfortunately, neither firm was willing to provide us with information that could enable us to estimate the proportion of the shares whose gains and losses are reported on personal tax returns.

${ }_{9}^{9}$ This argument follows from findings such as Landsman and Shackelford (1995) who report that when RJR Nabisco shareholders were forced to liquidate their shares in the firm's 1989 leveraged buyout, shareholders facing smaller capital gains taxes accepted lower prices than did shareholders facing larger capital gains taxes. They infer that stock prices partially rose between the original tender offer and the completion of the acquisition to compensate shareholders for their long-term capital gains.
} 
Second, recent studies of settings where taxes should be unusually important (e.g., when the tax law changes) have produced evidence consistent with shareholder's capital gains taxes affecting stock prices. The distinctive feature of this paper (which is discussed further in Section II) is that we find that personal capital gains taxes matter in a setting that does not appear to bias toward finding a tax effect. Despite the absence of any information about taxes in the S\&P announcement, taxes appear to affect the pricing of the largest, most closely followed, most efficiently priced, publicly-traded U.S. companies.

The next section reviews the recent capital gains tax capitalization literature and highlights this paper's distinctive contribution. Section II presents the empirical design. Section III discusses the empirical findings. Closing remarks follow.

\section{Tax Capitalization}

The effect of shareholder taxes on stock prices is central to firm valuation and has long intrigued scholars in finance, economics, accounting, and related fields (e.g., Elton and Gruber (1970), Miller (1977), Auerbach (1979), Kalay (1992), Poterba and Summers (1984), Scholes and Wolfson (1992), Fama and French (1999), Auerbach and Hassett (2000), among many others). The literature has focused principally on the capitalization of dividend taxes (i.e., whether stock prices reflect the taxes levied on dividend distributions). The area is marked by lack of consensus, ranging from Miller and Scholes's $(1978,1982)$ tax irrelevance (i.e., the marginal investor is a tax-exempt organization) to Harris, Hubbard, and Kemsley's (2000) report of extensive dividend tax capitalization in multiple countries.

Recently, several studies have investigated the impact of another shareholder-level tax on equilibrium stock prices. These studies focus primarily on the impact of capital gains taxes on 
equilibrium prices, testing whether stock prices reflect individuals' long-term capital gains taxes. Examples include: Guenther and Willenborg (1999) who find IPO prices increased following implementation of a special 50 percent capital gains tax exclusion for small offerings, and Lang and Shackelford (2000) who document that non-dividend-paying firms outperformed other firms during the May 1997 week when Congress and the White House agreed to reduce the long-term capital gains tax rate. As with the dividend capitalization studies, conclusions are not uniform. For example, Erickson (1998) finds little evidence that target shareholders' capital gains taxes affect mergers and acquisitions.

This paper contributes to a different stream of capital gains tax capitalization studies that calibrate the temporary price pressure created by capital gains taxes when market or tax conditions change. The central question in the price pressure papers is: Do buyers and sellers share taxes and tax savings associated with altering the timing of capital gains and loss transactions? These studies exploit cross-sectional differences in stock appreciation and crosstemporal differences in short-term and long-term capital gains taxes to distinguish between capital gains tax considerations and other factors.

For example, examining depreciated firms, Poterba and Weisbrenner (2000) show that from 1970-1978, the prices of equities that had declined during the capital gains holding period (six months at that time) rebounded following year-end. This is consistent with price reversal following a tax-induced, year-end sell-off intended to ensure favorable short-term capital loss treatment. Examining appreciated firms, Reese (1998) reports that trading volume increases and prices fall when the initial public shareholders first qualify for long-term capital gains tax treatment, consistent with a sell-off when lower long-term capital gains tax rates first apply. Blouin, Raedy and Shackelford (2000) also analyze initial public shareholders first qualifying for 
long-term capital gains tax rates. They report that when the long-term capital gains holding period was shortened in 1998, trading volume increased and share prices fell for one day and then immediately rebounded, for individuals first qualifying for the lower long-term rates. Guenther (2000) too focuses on a legislative change. He fails to detect the normal price movements for firms around ex-dividend dates (price decline before ex-dividend date, price rebound the following day) around the 1997 decision to reduce long-term capital gains tax rates. He attributes the unusual trading to tax-driven price pressure.

This paper also tests whether returns around the S\&P 500 inclusion are consistent with price pressure associated with differences in long-term and short-term taxes. Evaluating both appreciated and depreciated firms, it evaluates a setting that should not bias in favor of finding that capital gains taxes matter. The previous studies of capital gains tax-motivated price pressure focus on specialized settings where taxes should be unusually salient (e.g., changes in tax policy), periods when tax planning is prevalent (e.g., year-end), companies held disproportionately by individuals (e.g., IPOs), and transactions where taxes are important considerations (e.g., mergers and acquisitions). By evaluating index additions, events that should be independent of individuals' personal capital gains taxes, this study can better assess whether the prior findings in support of capitalization reflect exceptions to the rule (i.e., only occur under special tax conditions) or whether they illustrate a more general pricing role for capital gains taxes. 


\section{Research Design}

\section{A. Regression Equation}

The empirical tests are designed to assess whether stock price reactions to a firm joining the S\&P 500 index are consistent with mutual funds compensating individuals for incremental short-term capital gains. Regression analysis is employed to test for a relation between stock returns on the first trading day following the S\&P announcement and a measure of the incremental taxes incurred if a shareholder sells before shares qualify for long-term capital gains treatment.

Our incremental tax measure has both tax rate and tax base components. The rate is the difference between short-term and long-term capital gains tax rates (i.e., 19.6 percent under current maximum federal law). The base is the sales price less the tax basis, expressed as a percentage of the tax basis. Since we cannot observe an individual investor's cost basis in his shares, we estimate the taxable gain as the difference between share prices immediately preceding the S\&P announcement and share prices at the beginning of the long-term capital gains holding period (one year under current law). Thus, suppose a stock trades at $\$ 20$ immediately preceding announcement of its inclusion in the index, and it traded at $\$ 16$ one year earlier. Under current law, the tax measure in this study would be 0.049 (the 25 percent appreciation during the year times the current rate differential of 19.6 percent).

A positive relation is predicted between share returns and the tax measure. In other words, the larger the tax measure (i.e., the additional taxes triggered if an appreciated stock is sold before favorable long-term rates apply), the more stock prices rise to entice individuals to sell shares that face short-term rates. Likewise, the larger the tax savings from selling 
depreciated stock that creates short-term capital losses, the smaller the share price reaction to the S\&P 500 announcement as buyers and sellers share the tax savings through lower prices.

To test whether stock prices are increasing in incremental taxes, we estimate equation (1):

$$
\begin{aligned}
& A R_{i t+1}=\beta_{0}+\beta_{1} D R A T E_{t+1}+\beta_{2} \triangle P A S T_{i t}+\beta_{3} D R A T E_{t+1} * \triangle P A S T_{i t}+\beta_{4} D E M A N D_{t+1}+\varepsilon_{i t} \\
& \text { where: } A R_{i t+1}= \text { firm i's abnormal return on day } \mathrm{t}+1 \text { using a market model where beta } \\
& \text { is estimated for the } 100 \text { days preceding day } \mathrm{t} \text { and } \mathrm{t} \text { is the day of the } \\
& \text { announcement that firm } \mathrm{i} \text { is joining the } \mathrm{S} \& \mathrm{P} 500 ; \\
& D R A T E_{t+1}= \text { the maximum statutory short-term capital gains tax rate less the } \\
& \text { maximum statutory long-term capital gains tax rate on day } \mathrm{t}+1 ; \\
& \triangle P A S T_{i t}= \text { the difference between firm i's stock price at day } \mathrm{t} \text {, adjusted for stock } \\
& \text { splits and stock dividends, and its stock price at day } \mathrm{t}+1-\mathrm{n} \text { (where } \mathrm{n} \text { is } \\
& \text { the number of days in the long-term capital gains holding period on } \\
& \text { day } \mathrm{t}+1 \text { ) divided by its stock price at day } \mathrm{t}+1-\mathrm{n} ;
\end{aligned}
$$

Each variable is discussed in detail below. In short, DRATE measures the difference in short-term and long-term capital gains tax rates. $\triangle P A S T$ measures the appreciation during the current long-term capital gains holding period. Together $(D R A T E * \triangle P A S T)$ they comprise the tax variable. A positive coefficient on $D R A T E * \triangle P A S T$ will indicate that the stock returns on the first trading day following the S\&P announcement are increasing in the tax measure. Such a finding will be interpreted as evidence that (i) mutual funds compensate individual shareholders based on the incremental taxes associated with selling appreciated stock before long-term qualification and (ii) mutual funds and individual shareholders share in the latter's tax savings associated with selling depreciated stock before long-term qualification.

\section{B. Sample}

We purchased from Standard \& Poor's a list of the 518 firms added to the S\&P 500 from January 1, 1978 to December 31, 1999. From the Standard \& Poor's list, we delete 70 additions 
attributable to restructurings of existing S\&P 500 firms and 22 additions for which data are missing. The final sample includes $426 \mathrm{~S} \& \mathrm{P} 500$ additions. Five firms are included twice in the sample. Annual additions range from six in 1992 to 35 in both 1998 and 1999. Before October 1989, S\&P 500 announcement and addition dates were identical. Since then, the announcement has preceded the addition by seven days, on average.

Because S\&P announces additions to the index after the market closes, abnormal returns are computed on the day following the announcement $($ day $t+1)$. Descriptive statistics in Table I show that for the sample firms $A R$ on the first trading day following the announcement ranges from -5 percent to 21 percent with a mean (median) of 3.9 (3.6) percent.

\section{Tax Measure}

The ideal tax measure would capture the change in capital gains taxes, if any, that individual shareholders encounter if they sell shares at the S\&P 500 announcement date and face the short-term capital gains tax rate rather than sell in the future when the long-term rate applies. Unfortunately, we cannot observe individual investors' marginal tax rates, holding periods or total portfolio of realized gains and losses, all of which are necessary to compute the ideal tax measure. Instead we employ a cruder measure, the product of differences in short-term and long-term rates (DRATE) and a measure of the taxable base $(\triangle P A S T)$.

$D R A T E$ is the maximum federal short-term capital gains tax rate less the maximum federal long-term capital gains tax rate at disclosure. ${ }^{10}$ It is 35 percent for the first ten months of

\footnotetext{
${ }^{10}$ The assumption of maximum tax rates seems reasonable based on the predominance of capital gains among such individuals. According to the latest analysis of individual income tax returns (1997 returns) by the Statistics of Income (Internal Revenue Service (1999a, 1999b)), individuals in the maximum tax bracket (39.6 percent) accounted for 61 percent of all net capital gains (long-term and short-term capital gains less long-term and shortterm capital losses). The percentage increases to 75 percent when individuals in penultimate bracket (36 percent) are also considered.
} 
1978, 42 percent from then to June 9, 1981, 50 percent the remainder of 1981, 30 percent from

1982-1987, 10.5 percent in 1987, 0 from 1988-1990, 3 percent from 1991-1992, 11.6 percent

from 1993 to May 6, 1997, and 19.6 percent since then. ${ }^{11}$

DRATE captures the marginal difference between short-term and long-term classification for individuals in the top tax bracket who met two conditions. One, their total portfolio of realized long-term capital gains equals or exceeds long-term capital losses. Two, their total portfolio of realized short-term capital gains equals or exceeds short-term capital losses. ${ }^{12}$ These conditions are likely met for most individual investors during the investigation period. ${ }^{13}$ During the late 1970s and early 1980s, high inflation caused most stocks to appreciate (recall taxes are computed on nominal, not real income). Since then, the bull market has caused most stocks to appreciate.

$\triangle P A S T$ is the percentage change in stock prices during the previous six, 12 or 18 months. The applicable duration depends on the long-term capital gains holding period at the time of the $\mathrm{S} \& \mathrm{P}$ announcement. The holding period is one year for all days, except June 23, 1985 through June 30, 1988, when it is six months, and July 29, 1997 through December 31, 1997, when it is 18 months. ${ }^{14}$

\footnotetext{
${ }^{11}$ Any state variation in short-term and long-term capital gains tax rates is ignored.

${ }^{12}$ If both conditions hold, then postponing one dollar of gain until it qualifies as a long-term capital gain reduces total taxes by 19.6 cents, from 39.6 cents to 20 cents under current tax rates. If either condition does not hold (i.e., total short-term capital losses exceed total short-term capital gains or total long-term capital losses exceed total longterm capital gains), then the same marginal tax rate applies to a capital gain or loss, no matter whether it is long-term or short-term (see Shackelford (2000) for proof).

${ }^{13}$ According to the latest analysis of individual income tax returns (1997 returns) by the Statistics of Income, individuals in the maximum tax bracket (39.6 percent) reported $\$ 169$ billion of long-term capital gains and only $\$ 5$ billion of long-term capital losses and $\$ 16$ billion of short-term capital gains and $\$ 8$ billion of short-term capital losses (Internal Revenue Service (1999a, 1999b)).

${ }^{14}$ Throughout the investigation period, the long-term capital gains holding period is determined by the date of sale with one exception. The holding period is six months for assets purchased after June 22, 1984 and before January 1, 1988. Therefore, it is unclear whether investments sold from December 24, 1984 through June 22, 1985 face the new six-month holding period or the prior 12-month holding period. We assume a 12-month holding period; however, results are qualitatively insensitive to assuming a 6-month holding period. Similarly, sales during the first half of 1988 may have faced either a six-month holding period or a 12-month holding period. Because no sale
} 
This duration is selected because the difference between long-term and short-term rates is most relevant for investors who are nearest long-term qualification at the S\&P announcement. Thus, $\triangle P A S T$ is computed as though the marginal investor is an individual who has held the stock for precisely one day less than necessary to obtain long-term capital gains tax treatment. Such an individual would have the greatest incentive to postpone a sale and receive long-term capital gains tax treatment or accelerate a sale and receive short-term capital gains tax treatment. $\triangle P A S T$ ranges from -53 percent to 513 percent with a mean (median) of 36 (20) percent. Seventy-seven percent of additions report positive $\triangle P A S T$.

Returns may be increasing in $\triangle P A S T$ for at least two non-tax reasons. First, Jegadeesh and Titman (1993), Bernard, Thomas and Wahlen (1997) and Raedy (2000), among others, show that stocks that experience short-term positive (negative) returns will continue to experience positive (negative) returns for the next few quarters. Second, to the extent prices have risen during the holding period, tax costs associated with selling have increased, even for investors unaffected by the long-term/short-term capital gains tax tradeoffs investigated in this paper. For example, when prices are rising, an individual who has held shares for more than the long-term holding period faces increasing long-term capital gains taxes. Thus, sellers may demand compensation to cover the additional taxes. Although different from the incremental short-term capital gains tax effects examined here, this much-discussed "lock-in" effect (see Holt and Shelton (1962), Berman (1999), Klein (1999), among many others) may induce a positive coefficient on $\triangle P A S T .^{15}$

during the first half of 1988 could have qualified for long-term treatment unless it had been purchased before 1988 and thus faced a six-month holding period, we assume a six-month holding period for all sales in the first half of 1988; however, results are qualitatively insensitive to assuming a 12-month holding period.

${ }^{15}$ This paper investigates incentives to accelerate (defer) selling depreciated (appreciated) property weeks or months based on distinctions in short-term and long-term capital gains tax rates, a relatively unexplored issue. The more widely-studied "lock-in" effect addresses incentives to defer selling appreciated property to exploit the time value of money and/or the step-up in tax basis at death. 
Alternatively, returns may be declining in $\triangle P A S T$ because of leakage associated with S\&P additions in the earlier years of the investigation period. As noted above, before October 1989 , the S\&P added firms on the day of the announcement. Reportedly, investors speculated about future additions to the index (New York Times, May 21, 1986). If so, the $\triangle P A S T$ measurement period may include price increases attributable to speculation about a firm joining the index.

Both DRATE and $\triangle P A S T$ are separately included in the regression to ensure that variations in these components do not affect the interpretation of the coefficient on their product. No prediction is advanced for the coefficients on either variable, when they are included separately in the regression. However, reasons for both directional signs for the coefficient on $\triangle P A S T$ are discussed above.

More importantly for this study, a positive coefficient on the product of DRATE and $\triangle P A S T$ will indicate that returns are increasing in our measure of the incremental capital gains taxes. Such a finding will be interpreted as evidence that capital gains taxes positively affect stock returns to S\&P 500 index additions.

\section{Control Variable}

$D E M A N D$ is designed to control for changes in the demand by index funds over the investigation period. It is the percentage of equity mutual fund assets held in index funds, as shown in Bogle's (1999) Exhibit V, Money (April 1999, p.102), and Brennan (1999). ${ }^{16}$ Consistent with a dramatic increase in the number and holdings of S\&P 500 index funds during

\footnotetext{
${ }^{16}$ Results for the variable of interest are qualitatively unaltered if $D E M A N D$ is dropped from the regression or alternative measures of demand from index funds are used, including Vanguard's number of index funds, Vanguard's percentage of assets in index funds, and natural logarithm of Vanguard's index fund assets, all as reported in Bogle (1999).
} 
the investigation period, DEMAND increases steadily from 0.2 percent in 1978 to 8.0 percent in 1999. The percentage decreased in only two years, 1983 and $1986 .{ }^{17}$ As index funds have become more active in the equity markets, the demand for shares when firms join the S\&P 500 should have increased accordingly. If increased demand for shares creates upward price pressure, a positive coefficient is expected on DEMAND.

\section{Univariate relations}

Table II provides Pearson and Spearman correlation coefficients for all regression variables. As expected, abnormal returns on the first trading day following an S\&P addition announcement $(A R)$ are increasing in $D E M A N D$, consistent with price pressure increasing in index fund investments. Abnormal returns also are negatively correlated with DRATE, implying abnormal returns were greatest (smallest) in the late 1980s (1970s), though not necessarily because of tax rate differences.

A negative relation is detected between $A R$ and $\triangle P A S T$ using the Pearson correlation. This is consistent with additions leaking to the market or the market speculating on additions. The relation is never significant between $A R$ and the tax measure (the interaction of DRATE and $\triangle P A S T)$. This is not surprising since the univariate relations are unable to control for the separate effects of DRATE and $\triangle P A S T$.

However, when observations are sorted on DRATE, a pattern emerges among the univariate relations between $A R$ and $\triangle P A S T$ that is suggestive of capital gains tax distortion. For the 254 observations when DRATE is 19.6 or less, the Pearson (Spearman) correlation

\footnotetext{
${ }^{17}$ Besides capturing the intended increase in demand from S\&P 500 index funds over time, the coefficient on $D E M A N D$ may capture other unspecified intertemporal changes. The only intertemporal institutional change that we are aware is that before October 1989, announcements coincided with additions to the index. Now announcements precede additions.
} 
coefficient between $A R$ and $\triangle P A S T$ is $-0.21(-0.18)$. For the remaining 172 observations when $D R A T E$ is 30 or greater, the Pearson (Spearman) correlation coefficient between $A R$ and $\triangle P A S T$ is $0.10(-0.02)$. In other words, stock returns are increasing in appreciation more when the spread between short-term and long-term capital gains tax rates is greater. These univariate relations provide preliminary evidence consistent with the prediction that capital gains taxes affect stock returns around S\&P 500 announcements.

\section{Empirical Results}

\section{A. Primary Findings}

The regression analysis confirms the preliminary inferences drawn from the univariate relations. The first row in Table III presents regression coefficient estimates when abnormal returns are computed for the first trading day following announcement of an inclusion to the S\&P 500 (trading day $\mathrm{t}+1$ ). As predicted, the regression coefficient estimate on $D R A T E * \triangle P A S T$ is positive and significant at the 0.01 level ( $t$-statistic of 2.7$).{ }^{18}$ The evidence is consistent with individual investors' capital gains taxes boosting returns when S\&P announces an addition to the 500 index.

The regression coefficients enable estimates of economic significance. For example, the product of $D R A T E * \triangle P A S T$ 's regression coefficient estimate of 6.79 and its mean value of 0.07 implies that the tax premium accounts for one-day abnormal returns of 0.48 percent (121 percent annualized), on average. Furthermore, a one standard deviation increase in $D R A T E * \triangle P A S T$

\footnotetext{
${ }^{18}$ Throughout the paper, if the null hypothesis of correct model specification under White's (1980) test is rejected at conventional levels, the reported standard errors are computed using White's (1980) consistent covariance matrix estimation to correct for an unspecified form of heteroskedasticity. However, the results are qualitatively unaltered if ordinary least squares standard errors are always used. In addition, to mitigate the impact of outliers, we drop from each regression in the paper any observation with a studentized residual exceeding five. Conclusions, however, are unchanged if no outliers are deleted.
} 
(the incremental tax measure) boosts abnormal returns by 1.02 percent ( 257 percent annualized). ${ }^{19}$

Review of the other coefficients reveals that the coefficient on DRATE, for which no prediction is offered, is not significantly different from zero. As in the univariate relations, the coefficient on $\triangle P A S T$ is negative and significant. ${ }^{20}$ As expected, the coefficient on DEMAND is positive, consistent with the price pressure increasing as index funds become larger market participants. As an interesting aside, this result is not consistent with the hypothesis that S\&P 500 announcement returns are driven by information effects as discussed by Jain (1987) and Dhillon and Johnson (1991), among others.

\section{B. Price Reversion}

If the capital gains tax-motivated price movements are temporary, then prices should revert back to original levels when index firms cease rebalancing, i.e., the tax premium should evaporate. A difficulty in structuring a test of reversal is that theory is not rich enough to predict the reversal period. Because both Harris and Gurel (1986) and Lynch and Mendenhall (1997) document that a firm's trading volume quickly returns to near-normal levels following its addition to the index, we test for price reversal in the period immediately following the announcement. Specifically, the dependent variables in the price reversal tests are abnormal returns for trading days $\mathrm{t}+2$ through $\mathrm{t}+10$. All other variables are retained and measured identically. If prices reverse, the coefficient on $D R A T E * \triangle P A S T$ should flip signs, i.e., become

\footnotetext{
${ }^{19} 1.02$ percent is the product of $D R A T E * \triangle P A S T$ 's standard deviation of 0.15 and its regression coefficient estimate of 6.79 .

${ }^{20}$ Consistent with the leakage explanation discussed above, the coefficient on $\triangle P A S T$ is less negative if the $\triangle P A S T$ measurement period concludes one month preceding the S\&P 500 announcement and insignificant if years before 1990 are excluded from the study.
} 
negative.

The remaining rows in Table III reports results for the price reversion tests. The Fvalues for the nine reversal regressions are not significant on seven days, and the coefficient on $D R A T E * \triangle P A S T$ is never significantly different from zero. At first blush, little evidence emerges of any capital gains price responses during this period.

However, the sign of the interaction coefficient is negative on the fifth, sixth, and seventh trading days following the announcement and significant at roughly the 0.10 level using a onetailed test for the first two days of this sequence. Reestimating the model using three-day, cumulative, buy-and-hold abnormal returns beginning with trading day $\mathrm{t}+5$ (the first day with a negative $D R A T E * \triangle P A S T$ coefficient), we find that the coefficient on $D R A T E * \triangle P A S T$ is negative (-5.52) and significant at the 0.05 level. This finding is suggestive of some price reversal approximately one week following the announcement.

To estimate the extent of the reversal, we reestimate the equation using four-day, cumulative, buy-and-hold abnormal returns beginning with $\mathrm{t}+1$ and ending with the day preceding the beginning of the apparent reversal period. The coefficient on $D R A T E * \triangle P A S T$ in this model is 9.51 and significant at the 0.01 level. Comparing the coefficients for the first four days (when the coefficient on $D R A T E * \triangle P A S T$ is positive) and the subsequent three days (when the coefficient on $D R A T E * \triangle P A S T$ is negative), it appears that approximately 58 percent (5.52/9.51) of the capital gains tax distortion reverses by the end of the seventh trading day.

Thus, we conclude that the price responses to the capital gains taxes partially reverse in the days immediately following the announcement. Complete reversion may occur in a period subsequent to our analysis. One reason that reversal might be delayed is that investors may be 
unable immediately to fully disentangle price movements attributable to capital gains tax distortion from price movements for other reasons. If so, prices may reverse slowly.

\section{Tax Incidence}

The regression coefficients enable several assessments of tax incidence. Let $\alpha$ be the ratio of the expected after-tax proceeds from selling shares following long-term capital gains qualification to the after-tax proceeds from selling shares at the post-announcement price and paying short-term capital gains taxes:

$$
\alpha=\frac{1+\mathrm{E}\left[G_{L}\right]\left(1-\tau_{L}\right)}{1+G_{S}\left(1-\tau_{S}\right)}
$$

where $G$ equals the capital gains, $\tau$ is the capital gains tax rate, and $L(S)$ denotes long-term (short-term) classification. ${ }^{21}$ (Note that throughout this section, the discussion centers on index funds bearing part of the seller's tax burden. However, as in the remainder of the paper, the analysis also applies to index funds enjoying part of the seller's tax savings through realizing short-term capital losses, rather than long-term capital gains.)

If $\alpha<1$, then individual investors maximize after-tax returns by selling immediately and paying short-term capital gains taxes. For example, $\alpha<1$ if the extraordinary price increases following the America Online and Yahoo! announcements (discussed above) are presumed to be transitory. ${ }^{22}$ In other words, under these assumptions, the price increases following these

\footnotetext{
${ }^{21}$ The expectations operator is used for long-term capital gains because they cannot be realized until the future. It is not used for short-term capital gains because they can be realized immediately. Discount rates are ignored throughout this analysis because the long-term capital gains holding periods throughout the investigation period are never greater than 18 months. The tax basis throughout this analysis is $\$ 1$ per share.

${ }^{22}$ If $G_{L}$ is America Online's 452 percent appreciation in the year preceding announcement and $G_{S}$ adds its 33 percent surge following announcement to the 452 percent appreciation, then $\alpha$ is 0.96 , using current maximum federal tax rates. If $G_{L}$ is Yahoo!'s 122 percent appreciation in the preceding year and $G_{S}$ adds its 64 percent jump following announcement to the 122 percent appreciation, then $\alpha$ is 0.75 .
} 
additions more than compensated individual investors for their incremental short-term capital gains.

If $\alpha>1$, then individual investors maximize after-tax returns by deferring selling and facing long-term capital gains tax rates in the future. For example, if $\mathrm{E}\left[G_{L}\right]=G_{S}$ and $\tau_{S}>\tau_{L}$, then $\alpha>1$. In other words, if the expected capital gain when the stock qualifies for long-term capital gains taxation equals the post-announcement price, then an individual investor should defer, assuming short-term rates exceed long-term rates, which they have in all years except 1988-1990.

To estimate the $\mathrm{E}\left[G_{L}\right]$ that leaves $\alpha=1$, (i.e., individual investors indifferent), we make the following assumptions: $G_{S}$ is the appreciation following the announcement (mean $\triangle P A S T$ of 36 percent increased by the mean $A R$ of 3.88 percent $\left.\left\{\left(1.36^{*} 1.0388\right)-1\right\}\right) . \tau_{L}$ is the mean long-term capital gains tax rate during the investigation period ( 25 percent). $\tau_{S}$ is 46 percent, $\tau_{L}$ plus the mean DRATE of 21 percent.

Solving for $\mathrm{E}\left[G_{L}\right]$ using these parameters, we find that individual investors are indifferent between selling and holding if $\mathrm{E}\left[G_{L}\right]$ equals 30 percent. That is, share prices fall 8 percent from their post-trading day $\mathrm{t}+1$ level ( $G_{S}$ 's 41 percent appreciation). Alternatively stated, share prices fall 4 percent from their pre-announcement levels (36 percent appreciation). ${ }^{23}$

On the other hand, suppose the announcement price increase is fully transitory and share prices return to their prior levels and remain there until long-term qualification is reached. How much temporary price pressure would be needed to leave individual investors indifferent

\footnotetext{
${ }^{23}$ The post-trading day $\mathrm{t}+1$ price is $\$ 1.41$ ( $G_{S}$ appreciation on the $\$ 1$ tax basis). The pre-announcement price is $\$ 1.36$ (mean $\triangle P A S T$ appreciation of 31 percent on the $\$ 1$ tax basis). $\$ 1.41$ less an 8 percent decline (or $\$ 1.36$ less a 4 percent decline) equals $\$ 1.30$ ( $\$ 1$ tax basis plus the computed $\mathrm{E}\left[G_{L}\right]$ appreciation).
} 
between holding and selling (i.e., $\alpha=1$ )? Retaining the original parameters and setting $\mathrm{E}\left[G_{L}\right]$ equal to the mean $\triangle P A S T$, we find $G_{S}$ equals 50 percent. In other words, temporary pressure must boost share prices by 10.29 percent at the announcement (from 36 percent appreciation to 50 percent appreciation), more than double the mean $A R$ of 3.88 percent. In other words, the positive abnormal returns observed in this study are inadequate to fully compensate individual investors for their incremental short-term capital gains under these conditions.

How much greater would the tax premium have to be for the tax incidence to fall fully on the buyer? Based on the regression coefficient estimates, the tax premium appears to boost abnormal returns by 0.48 percent (the product of $D R A T E * \triangle P A S T$ 's regression coefficient estimate on trading day $t+1$ of 6.79 and its mean value of 0.07 ) with the remaining abnormal returns ( 3.88 percent less 0.48 percent) attributable to non-tax reasons. If the non-tax returns remain constant, the abnormal returns related to the tax premium would have to be 6.89 percent $(10.29-3.88+0.48)$ to fully shift the tax burden to buyers. Thus, the current tax premium of 0.48 percent appears to shift only 7 percent of the seller's incremental capital gains to buyers through higher share prices on the day following the inclusion announcement.

Because the tax premium only compensates a portion of the incremental taxes, many individual investors facing short-term capital gains likely are not enticed to sell by the current tax premium. However, apparently the partial compensation is sufficient to entice enough individuals to sell that indexers' demand is met.

\section{Sensitivity Tests}

We conduct a battery of sensitivity tests to assess the robustness of the results. One, to test whether the findings hold for both individuals with depreciated shares and individuals with 
appreciated shares, we reestimate equation (1) for the first trading day separately depending on the sign of $\triangle P A S T$. Both depreciated and appreciated additions have positive and similarly significant coefficients on $D R A T E * \triangle P A S T$.

Two, to assess the importance of the separate regressors for DRATE and $\triangle P A S T$, we reestimate the model without them. Inferences are qualitatively unaltered if the separate DRATE regressor is excluded from the regression, consistent with DRATE 's insignificant coefficient. Conversely, the coefficient on $D R A T E * \triangle P A S T$ is not significantly different from zero on the first trading day when the separate $\triangle P A S T$ regressor is excluded from the model. When $\triangle P A S T$ is excluded, the negative relation between returns and $\triangle P A S T$ (found in the original regression) apparently applies a downward bias on the interaction, rendering it no longer significantly positive.

Three, as discussed above, marginal tax rates for capital gains and losses are determined annually. Thus, tax planning could become more precise as individuals near year-end. However, we find no such evidence. Inferences are qualitatively unchanged when the disclosures in December are deleted from the study ( DRATE * $\triangle P A S T$ 's coefficient for trading day $\mathrm{t}+1$ is 6.00 with a $t$-statistic of 2.3 ) and when the disclosures in October, November, and December are deleted from the study ( $D R A T E * \triangle P A S T$ 's coefficient for trading day $\mathrm{t}+1$ is 8.83 with a $t$-statistic of 3.6).

Finally, several additional regressions are conducted. None alter the conclusions. First, the model is reestimated without the 59 additions from 1988 to 1990 , the only years when no long-term rate differential exists. $D R A T E * \triangle P A S T$ 's coefficient for trading day $\mathrm{t}+1$ is 6.65 with a $t$-statistic of 2.4. Second, the maximum federal personal income tax rate (same as the shortterm capital gains tax rate) is included in the model. DRATE * $\triangle P A S T$ 's coefficient for trading 
day $\mathrm{t}+1$ is 6.77 with a $t$-statistic of 2.6 . The coefficient on the individual rate is not significantly different from zero. Third, the maximum federal corporate income tax rate is included in the model. $D R A T E * \triangle P A S T$ 's coefficient for trading day $\mathrm{t}+1$ is 6.86 with a $t$-statistic of 2.6. The coefficient on the corporate rate is not significantly different from zero.

\section{Conclusion}

This paper contributes to our understanding of the determinants of price responses to inclusion in the S\&P 500 by providing evidence consistent with capital gains tax planning impacting stock reactions. Tests are conducted on 426 additions from 1978-1999. We regress the returns on the first trading day following announcement on a capital gains tax measure and controls. The evidence is consistent with abnormal returns at the S\&P announcement increasing in the difference in the incremental short-term capital gains taxes that would be paid if individual investors sold their appreciated shares immediately. Similarly, the findings are consistent with returns declining in the incremental short-term capital loss tax savings that would be enjoyed if individuals sold their depreciated shares immediately. We infer from these findings that in rebalancing their portfolios after S\&P 500 additions, index funds share individual shareholders' capital gains taxes (or tax savings) through sales price adjustments. Consistent with temporary

price pressure, further analysis shows that much of the price reaction unwinds over the following week's trading.

Finally, besides expanding our understanding of the price reactions to index inclusions, finding that personal capital gains taxes affect stock returns in a setting that does not bias toward taxes mattering suggests that capital gains tax capitalization may be a pervasive feature in equity 
valuation. Unlike prior studies that arguably bias toward finding a tax effect in their attempt to maximize power, this result arises where no tax information appears to be conveyed. 


\section{References}

Auerbach, A., 1979, Wealth maximization and the cost of capital, Quarterly Journal of Economics 93, 433-446.

Auerbach, A. and K. Hassett, 2000, On the marginal source of investment funds. National Bureau of Economic Research working paper 7821.

Berman, L., 1999, The Labyrinth of Capital Gains Tax Policy: A Guide for the Perplexed (Brookings Institution Press, Washington, D.C.).

Bernard, V., J. Thomas, and J. Wahlen, 1997, Accounting-based stock price anomalies: Separating market inefficiencies from risk, Contemporary Accounting Research 14, 89136.

Blouin, J., J. Raedy, and D. Shackelford, 2000, Capital Gains Holding Periods and Equity Trading: Evidence from the 1998 Tax Act, National Bureau of Economic Research working paper 7827.

Bogle, J., 1999, The first index mutual fund: A history of Vanguard index trust and the Vanguard index strategy, Vanguard web site, http://www.vanguard.com.

Brennan, J., 1999, Emerging trends in the mutual fund marketplace: A U.S. perspective, Vanguard web site, http://www.vanguard.com.

Dhillon, U., and H. Johnson, 1991, Changes in the Standard and Poor's 500 list, Journal of Business 64, 75-85.

Erickson, M., 1998, The effect of taxes on the structure of corporate acquisitions, Journal of Accounting Research 36, 279-298.

Elton, E. and M. Gruber, 1970, Marginal shareholder tax rates and the clientele effects, Review of Economics and Statistics 52, 68-74.

Fama, E. and K. French, 1999, Disappearing dividends: Changing firm characteristics or lower propensity to pay, Working paper, University of Chicago, Chicago, IL.

Guenther, D., 2000, Investor reaction to anticipated 1997 capital gains tax rate reduction, Working paper. University of Colorado, Boulder, CO.

Guenther, D., and M. Willenborg, 1999, Capital gains tax rates and the cost of capital for small business: Evidence from the IPO market, Journal of Financial Economics 53, 385-408. 
Harris, L., and E. Gurel, 1986, Price and volume effects associated with changes in the S\&P 500 list: New evidence for the existence of price pressures, Journal of Finance 41, 815-829.

Harris, T., R. Hubbard, and D. Kemsley, 2000, The share price effects of dividend taxes and tax imputation credits, Journal of Public Economics, forthcoming.

Holt, C., and J. Shelton, 1962, The lock-in effect of the capital gains tax, National Tax Journal $15,337-352$.

Internal Revenue Service, 1999a, Individual income tax returns, 1997, Statistics of Income Bulletin, Publication 1136.

Internal Revenue Service, 1999b, Individual income tax rates and shares, 1997, Statistics of Income Bulletin, Publication 1136.

Jain, P., 1987, The effect on stock price of inclusion in or exclusion from the S\&P 500, Financial Analysts Journal, 58-65.

Jegadeesh, N., and S. Titman, 1993, Returns to buying winners and selling losers: Implication of stock market efficiency, Journal of Finance 44, 135-148.

Kalay, A., 1992, The Ex-dividend day behavior of stock prices: A re-examination of the clientele effect, Journal of Finance 37, 1059-1070.

Kaul, A., V. Mehrotra, and R. Morck, 2000, Demand curves for stocks do slope down: New evidence from an index weights adjustment, Journal of Finance 55, 893-912.

Klein, P., 1999, The capital gain lock-in effect and equilibrium returns, Journal of Public Economics 71, 355-378.

Landsman, W., and D. Shackelford, 1995, The lock-in effect of capital gains taxes: Evidence from the RJR Nabisco leveraged buyout, National Tax Journal 48, 245-59.

Lang, M., and D. Shackelford, 2000, Capitalization of capital gains taxes: Evidence from stock price reactions to the 1997 rate reductions, Journal of Public Economics 76, 69-85.

Lynch, A., and R. Mendenhall, 1997, New evidence on stock price effects associated with changes in the S\&P 500 index, Journal of Business 70, 351-383.

Miller, M., 1977, Debt and taxes, Journal of Finance 32, 261-276.

Miller, M. and M. Scholes, 1978, Dividends and taxes, Journal of Financial Economics 6, 333364.

Miller, M. and M. Scholes, 1982, Dividends and taxes: Some empirical evidence, Journal of Political Economy 90, 1118-1141. 
Poterba, J. and L. Summers, 1984, New evidence that taxes affect the valuation of dividends, Journal of Finance 39, 1397-1415.

Poterba, J., and S. Weisbrenner, 2000, Capital gains tax rules, tax loss trading, and turn-of-theyear returns, Journal of Finance, forthcoming.

Raedy, J., 2000, A reconciliation of stock market anomalies, Working paper, University of North Carolina, Chapel Hill, NC.

Reese, W., 1998, Capital gains taxation and stock market activity: Evidence from IPOs, Journal of Finance 53, 1799-1820.

Scholes, M., and M. Wolfson, 1992, Taxes and Business Strategy: A Planning Approach, (Prentice-Hall, Inc., Englewood Cliffs, NJ)

Shackelford, D., 2000, Stock market reaction to capital gains tax changes: Empirical evidence from the 1997 and 1998 Tax Acts, in J. Poterba, ed.: Tax Policy and the Economy. Vol. 14 (National Bureau of Economic Research and MIT Press. Cambridge, MA), 67-92.

Shleifer, A., 1986, Do demand curves for stocks slope down? Journal of Finance 61, 579-590.

Shleifer, A., 2000, Inefficient Markets: An Introduction to Behavioral Finance (Oxford University Press: Oxford, Great Britain).

White, H., 1980, A heteroskedasticity-consistent covariance matrix estimator and a direct test for heteroskedasticity, Econometrica 48, 817-838. 


\section{TABLE I}

Descriptive Statistics for the Regression Variables Used in Tests of the Impact of Capital Gains Tax Planning on Stock Returns for 426 Additions to the Standard \& Poor's 500 from 1978-1999

$A R_{i t+1}$ is firm i's abnormal return on day $\mathrm{t}+1$ using a market model where beta is estimated for the 100 days preceding day $\mathrm{t}$, where $\mathrm{t}$ is the day of the announcement that firm $\mathrm{i}$ is joining the $\mathrm{S} \& \mathrm{P} 500 ; D R A T E_{t+1}$ is the maximum statutory short-term capital gains tax rate less the maximum statutory long-term capital gains tax rate on day $\mathrm{t}+1 ; \triangle P A S T_{i t}$ is the difference between firm i's stock price at day $\mathrm{t}$, adjusted for stock splits and stock dividends, and its stock price at day $\mathrm{t}+1-\mathrm{n}$ when $\mathrm{n}$ is the number of days in the holding period on day $\mathrm{t}+1$, divided by its stock price at day $\mathrm{t}+1-\mathrm{n} ; D E M A N D_{i t+1}$ is the percentage of equity mutual fund assets held in index funds.

\begin{tabular}{|l|c|c|c|c|c|c|c|}
\hline & mean & std dev & min & $25 \%$ & median & $75 \%$ & Max \\
\hline$A R$ & 3.88 & 3.27 & -4.93 & 1.83 & 3.56 & 5.35 & 20.87 \\
\hline$D R A T E$ & 0.21 & 0.13 & 0.00 & 0.12 & 0.20 & 0.30 & 0.50 \\
\hline$\triangle P A S T$ & 0.36 & 0.61 & -0.53 & 0.02 & 0.20 & 0.52 & 5.13 \\
\hline$D R A T E * \triangle P A S T$ & 0.07 & 0.15 & -0.18 & 0.00 & 0.03 & 0.10 & 1.03 \\
\hline$D E M A N D$ & 2.70 & 2.60 & 0.20 & 0.40 & 1.50 & 5.00 & 8.00 \\
\hline
\end{tabular}




\section{TABLE II}

\section{Pearson (Spearman) Correlation Coefficients Lie Above (Below) Diagonal for the Regression Variables Used in Tests of the Impact of Capital Gains Tax Planning on Stock Returns for 426 Additions to the Standard \& Poor's 500 from 1978-1999}

$A R_{i t+1}$ is firm i's abnormal return on day $\mathrm{t}+1$ using a market model where beta is estimated for the 100 days preceding day $\mathrm{t}$, where $\mathrm{t}$ is the day of the announcement that firm $\mathrm{i}$ is joining the $\mathrm{S} \& \mathrm{P} 500 ; D R A T E_{t+1}$ is the maximum statutory short-term capital gains tax rate less the maximum statutory long-term capital gains tax rate on day $\mathrm{t}+1 ; \triangle P A S T_{i t}$ is the difference between firm i's stock price at day $\mathrm{t}$, adjusted for stock splits and stock dividends, and its stock price at day $\mathrm{t}+1-\mathrm{n}$ when $\mathrm{n}$ is the number of days in the holding period on day $\mathrm{t}+1$, divided by its stock price at day $\mathrm{t}+1-\mathrm{n} ; D E M A N D_{i t+1}$ is the percentage of equity mutual fund assets held in index funds.

\begin{tabular}{|l|c|c|c|c|c|}
\hline & $A R$ & $D R A T E$ & $\Delta P A S T$ & DRATE $*$ PAST & DEMAND \\
\hline$A R$ & & $-0.11^{*}$ & $-0.11^{*}$ & -0.07 & $0.29 * *$ \\
\hline$D R A T E$ & $-0.17^{* *}$ & & 0.02 & $0.28^{* *}$ & $-0.37 * *$ \\
\hline$\triangle P A S T$ & -0.09 & 0.00 & & $0.86^{* *}$ & $0.27 * *$ \\
\hline DRATE $*$ PAST & -0.08 & $0.29 * *$ & $0.87^{* *}$ & & $0.11 *$ \\
\hline DEMAND & $0.23 * *$ & $-0.59 * *$ & $0.17 * *$ & 0.03 & \\
\hline
\end{tabular}

* denotes significance at 0.05 using two-tailed test

** denotes significance at 0.01 using two-tailed test 


\section{TABLE III \\ Summary Statistics from Ordinary Least Squares Regressions Testing the Impact of Capital Gains Tax Planning on Stock Returns}

For varying post-event windows, the following pooled, cross-sectional regression is estimated for 426 firms added to the Standard \& Poor's 500 index from 1978-1999.

$$
\text { Regression Model: } \quad A R_{i t+m}=\beta_{0}+\beta_{1} D R A T E_{t+1}+\beta_{2} \Delta P A S T_{i t}+\beta_{3} D R A T E_{t+1} * \Delta P A S T_{i t}+\beta_{4} D E M A N D_{t+1}+\varepsilon_{i t}
$$

$A R_{i t+m}$ is firm i's abnormal return on day $\mathrm{t}+\mathrm{m}$ using a market model where beta is estimated for the 100 days preceding day $\mathrm{t}$, where $\mathrm{t}$ is the day of the announcement that firm $\mathrm{i}$ is joining the S\&P 500 and $\mathrm{m}$ is the number of days following the announcement; DRATE $E_{t+1}$ is the maximum statutory short-term capital gains tax rate less the maximum statutory long-term capital gains tax rate on day $\mathrm{t}+1 ; \triangle P A S T_{i t}$ is the difference between firm i's stock price at day $\mathrm{t}$, adjusted for stock splits and stock dividends, and its stock price at day $\mathrm{t}+1-\mathrm{n}$ when $\mathrm{n}$ is the number of days in the holding period on day $\mathrm{t}+1$, divided by its stock price at day $\mathrm{t}+1-\mathrm{n} ; D E M A N D_{i t+1}$ is the percentage of equity mutual fund assets held in index funds. A positive coefficient on day $\mathrm{t}+1$ for $\beta_{3}$ is consistent with buyers and sellers sharing incremental taxes (or tax savings) associated with selling appreciated (depreciated) property immediately following announcement of an addition. A negative coefficient on subsequent days for $\beta_{3}$ implies reversal of the tax effect, consistent with temporary price pressure.

\begin{tabular}{|c|c|c|c|c|c|c|c|}
\hline & Intercept & DRATE & $\Delta P A S T$ & DRATE* ${ }^{*}$ PAST $(t$-stat) & DEMAND & adj. $\mathrm{R}^{2}$ & $\mathrm{mean}^{\text {AR }}$ \\
\hline$t+1$ & $3.36^{* *}$ & -1.49 & $-2.50^{* *}$ & $6.79(2.7)^{* *}$ & $0.45^{* *}$ & 0.13 & 3.88 \\
\hline$t+2$ & 0.25 & -0.72 & -0.11 & $0.46(0.3)$ & 0.01 & -0.01 & 0.13 \\
\hline$t+3$ & 0.15 & -0.70 & -0.43 & $1.01(0.9)$ & $0.10 *$ & 0.01 \\
\hline$t+4$ & 0.07 & -0.22 & $-0.77 *$ & $2.51(1.5)$ & 0.07 & 0.00 & 0.12 \\
\hline$t+5$ & 0.35 & -1.26 & 0.13 & $-1.73(-1.3)$ & 0.01 & 0.01 & 0.05 \\
\hline$t+6$ & -0.36 & 0.50 & 0.36 & $-1.95(-1.5)$ & 0.05 & -0.00 & -0.14 \\
\hline$t+7$ & 0.21 & -0.19 & 0.11 & $-1.19(-0.8)$ & -0.01 & -0.00 & 0.09 \\
\hline$t+8$ & -0.19 & 0.57 & $-0.76^{*}$ & $1.14(0.8)$ & 0.02 & 0.02 & -0.20 \\
\hline$t+9$ & -0.45 & 0.92 & -0.58 & $0.20(0.4)$ & 0.09 & 0.01 & -0.22 \\
\hline$t+10$ & 0.01 & -0.03 & 0.24 & $-0.99(-0.5)$ & $-0.09 *$ & 0.00 & -0.22 \\
\hline
\end{tabular}

* denotes significance at 0.05 using two-tailed test

** denotes significance at 0.01 using two-tailed test 